\title{
Middle Managers, Strategic Sensemaking, and Discursive Competence
}

\section{Linda Rouleau and Julia Balogun*}

\author{
HEC Montreal; Lancaster University
}

ABSTRACT This paper seeks to better understand the way middle managers contribute strategically to the development of an organization by examining how they enact the strategic roles allocated to them, with particular reference to strategic change. Through vignettes drawn from the authors' current research, a framework is developed that shows two situated, but interlinked, discursive activities, 'performing the conversation' and 'setting the scene', to be critical to the accomplishment of middle manager sensemaking. Language use is key, but needs to be combined with an ability to devise a setting in which to perform the language. The paper shows how middle managers knowledgeably enact these two sets of discursive activities by drawing on contextually relevant verbal, symbolic, and sociocultural systems, to allow them to draw people from different organizational levels into the change as they go about their day-to-day work.

\section{INTRODUGTION}

There is a growing body of research which shows the important strategic role middle managers play in both the formulation and implementation of strategic change (see for example, Balogun, 2003; Balogun and Johnson, 2004, 2005; Currie and Proctor, 2005; Dutton et al., 2001; Floyd and Wooldridge 1994, 1997; Hoon, 2007; Ling et al., 2005; Mantere, 2008; Rouleau, 2005; Westley, 1990). This research also highlights middle manager sensemaking capabilities as critical to the roles they perform. This focus on strategic sensemaking capabilities is not unique to middle managers. There is increasing evidence from existing research on both senior and middle managers of the need for them to exercise their strategic influence (Alexiev et al., forthcoming; Balogun et al., 2005, 2008; Buchanan, 2008; Fairhurst, 2007; Mangham and Pye, 1991; Pye and Pettigrew, 2005). Skilled managers are able to use their knowledge of their organizational context and their colleagues/subordinates/seniors to influence those around them to adopt their point of view.

Address for reprints: Linda Rouleau, HEC Montreal, 3000, chemin de la Côte Sainte-Catherine, Montreal, QC H3T 2A7, Canada (linda.rouleau@hec.ca).

*Author order is historical. Both authors contributed equally. 
Yet we still know little about how this strategic influencing is done, particularly by middle managers, who are a special case since they lack the formal role authority held by their seniors to act strategically. They need to influence upwards as well as laterally and downwards. Recent research does, however, suggest that discursive abilities are at the core of the way managers influence others (Maitlis, 2005; Maitlis and Lawrence, 2007; Maitlis and Sonenshein, 2010; Sonenshein, 2006; Wooldridge et al., 2008).

In this paper we therefore contribute to existing research on middle managers, their strategic roles and sensemaking by exploring their discursive abilities, how they are manifested and through which activities, when engaged in tasks related to change. We are not just interested in issue selling (Dutton et al., 2001), but the discursive abilities required to influence more generally at any stage of the change process, and on influencing activities across multiple stakeholders, upwards, downwards, and horizontally. The paper adopts a theory elaboration approach to develop our understanding of how middle managers contribute strategically. It draws on empirical vignettes taken from existing research on middle managers involved in implementing strategic change which provide insight into how middle managers accomplish their strategic assignments and contributions in practice.

Our analysis leads to the development of a framework which shows that two discursive activities, 'performing the conversation' and 'setting the scene', are central to middle managers' situated sensemaking as they perform their strategic roles, and that these two activities are underpinned by their ability to draw on symbolic and verbal representations and the sociocultural systems they belong to. The framework enables us to develop a deeper understanding of what we term middle manager discursive competence; a middle manager's ability to knowledgeably craft and share a message that is meaningful, engaging, and compelling within his/her context of operation. We extend the findings of Sonenshein (2006) and Maitlis (2005) since we show how specific language use needs to be interwoven with the building of relevant social settings in which to perform the conversations, and the necessity for language use to be embedded in the specifics of the context. Specifically, while Maitlis (2005) and Sonenshein (2006), and others (such as Dutton and Ashford, 1993; Dutton et al., 2001; Piderit and Ashford, 2003) show that the content and nature of conversations matter, our findings enable us to understand more of the detail surrounding these conversations, showing the importance of, for example, other relational aspects such as orchestration of the setting in which conversations are embedded as they unfold. In addition we show the need to understand context in terms of interrelationships between verbal and symbolic representations and sociocultural systems. We elaborate the 'skill' or 'craft' of middle manager sensemaking that underpins discursive competence and that lies in an intimate knowledge of the setting. As such we also respond to calls for a stronger focus on the actual activities managers engage in to accomplish their strategic work as part of the practice of strategy (Jarzabkowski et al., 2007; Johnson et al., 2003).

This paper first reviews what is known about middle managers and the sensemaking capabilities required in strategic roles. It then lays out the research methods and findings. Last, it derives a repertoire of activities from which four propositions are inferred regarding the nature of middle manager situated sensemaking during their accomplishment of change related strategic roles. The paper concludes with a consideration of the research contributions and the implications for practice. 


\section{MIDDLE MANAGERS AND STRATEGIC SENSEMAKING}

There is a growing body of research which explores the strategic roles and contributions of middle managers (Balogun, 2003; Dutton and Ashford, 1993; Floyd and Lane, 2000; Floyd and Wooldridge, 1994, 1997; Huy, 2002; Mantere, 2008; Raman, 2009; Yang et al., forthcoming). This research increasingly emphasizes middle manager sensemaking capabilities as critical to what they do in many different areas such as issue-selling when championing change (Dutton and Ashford, 1993; Dutton et al., 2001; Dutton et al., 1997; Ling et al., 2005; Piderit and Ashford, 2003) and communicating and diffusing the change intent when implementing strategic change (Balogun, 2003; Balogun and Johnson, 2004; Huy, 2002; Rouleau, 2005).

Sensemaking has been defined quite broadly by Weick (for example, 1995), although in much empirical research on change it is more generally conceptualized as a social process of meaning construction and reconstruction through which managers understand, interpret, and create sense for themselves and others of their changing organizational context and surroundings (Balogun and Johnson, 2004; Corley and Gioia, 2004; Gioia and Chittipeddi, 1991; Maitlis, 2005; Maitlis and Sonenshein, 2010; Pye, 1995; Watson and Bargiela-Chiappini, 1998). Mangham and Pye (1991) describe sensemaking more specifically as a dual, cyclical, and ongoing process of sense reading and sense wrighting to better portray the aspect of skilled practice concealed within sensemaking and sensegiving. Wrighting is used in the sense that a playwright "wrights" and a shipwright "wrights", (pp. 27-8). This distinction evokes the notion of individuals engaging in intertwined cycles of interpretation and action, where interpretation shapes action and vice versa in a reciprocal relationship through time, which is also intertwined with, and influenced by, the simultaneous cycles of interpretation and action of others (Balogun et al., 2008). Furthermore, it emphasizes the fact that this sensemaking occurs in a relational context. Intertwined and mutually reinforcing multiple acts of individual sensemaking shape the processes and outcomes of organizational sensemaking.

Thus these sensemaking studies do focus on, and inform what we know about, how managers influence others. Recent studies in particular highlight the importance of understanding multiple stakeholder interactions as part of organizational sensemaking and the role of language use. Maitlis (2005) shows that when attempting to influence others' understanding of an issue through sensegiving, the interactions between diverse stakeholders are relevant and must be taken into account. Maitlis and Lawrence (2007) further show sensegiving to be a fundamental situated leadership activity within organizational sensemaking, based on a discursive ability to tell a story in the right way at the right time and in the right place, although they do not empirically investigate this discursive ability. Sonenshein (2006) shows how managers use specific language to influence others in issue selling and emphasize individual effects on sensegiving. Other research on middle managers' strategic conversations reveals the nature of the micro conversational mechanisms by which middle managers generate a shared understanding of a change or sell an issue to top managers (Hoon, 2007; Laine and Vaara, 2007; Westley, 1990).

However, studies largely remain focused on unidirectional sensemaking and do not show the discursive competence involved in sensegiving in particular and that lies in 
intimate knowledge of the setting. They do not help us to develop an understanding of how middle managers deploy their discursive abilities in order to engage others in their projects. Furthermore, whilst most of the research on sensemaking emphasizes its social and interpretative character, it pays less attention to the relational process that is inherent to the process of meaning making that we highlight above, although recent research indicates that the relational context is important (Dutton et al., 2001). Indeed, there is a political dimension that has been neglected in the middle manager literature (Wooldridge et al., 2008). There is increasing evidence from research on both senior and middle managers of their need to be 'politically able', in other words, to be able to influence others, if they want to affect the course of the events around strategic change (Balogun et al., 2005, 2008; Buchanan, 2008; Fairhurst, 2007; Mangham and Pye, 1991; Pye and Pettigrew, 2005).

Research on the how of middle managers' sensemaking as they perform their strategic roles also needs to extend to include vertical and horizontal relationships. Most research on middle managers' strategic roles has investigated their downward (Balogun and Johnson, 2004) or upward (Dutton and Ashford, 1993; Dutton et al., 1997, 2001) influence, or a combination of both (Currie, 1999; Floyd and Lane, 2000). Yet middle managers are, for example, also important mediators across organizational boundaries (Balogun et al., 2005; Rouleau, 2005).

We therefore argue that strategic sensemaking does not exist just in cognitive structures or in routines and systems, it is constituted and reconstituted in ongoing discursive activities of middle managers (Taylor and Robichaud, 2004). In other words, strategic sensemaking is accomplished through the ability of middle managers to craft and share a message by referring to a complex mosaic of underlying knowledge (Samra-Fredericks, 2005) that is subtly invoked in order to make that message meaningful within the context. Moreover, since middle managers often lack the formal authority of those more typically associated with strategic work, such as members of upper echelons, they are potentially more reliant on their ability to sense read and wright, typically lacking other forms of persuasion or sanction, or the legitimacy critical to sensegiving (Maitlis and Lawrence, 2007), that accrues to those with hierarchical resource based means of influence. Yet research has rarely taken this argument seriously to examine empirically this largely recognized yet relatively unexplored multirelational, discursive, nature of what middle managers' do when acting strategically.

This paper therefore seeks to understand: (1) how the sensemaking required as part of a strategic role is discursively put into action by middle managers; and (2) through which activities the discursive competence is enacted by middle managers.

\section{METHODS}

This research seeks to elaborate existing theory on middle managers by drawing on data from two research projects established to explore middle manager practices in change situations. One project focuses on the transformation of middle managers' identity in organizational restructuring (see Rouleau, 2010). The data were collected through narratives of practice, also called work life stories (Bertaux and Delcroix, 2000). Middle managers were invited to narrate their professional trajectory with particular reference to 
the organizational restructuring they had just experienced. The other project explores how middle managers delivering change across organizational boundaries operate and relies on interview and focus group data (see Balogun et al., 2005).

These research projects were not explicitly designed to elicit the discursive competence of the middle managers respondents. However, both the datasets contain data on a number of middle managers that reveal their self-reflective views about the way they implement strategic change through their daily activities. The use of biographical methods in the first project encouraged middle managers to bring together actions, beliefs, and sense of self that are part of their sensemaking activity when telling their story of the organizational restructuring (Rouleau, 2010). The use of interactive discussion groups in the second allowed the researcher to know more about the values, attitudes, and representations that managers have, shared, and negotiated in real time (Balogun et al., 2003). Their strength lies in the snowball effect as individuals in their storytelling encourage deeper reflection from each other around activities they were engaged in.

In narrating their work life story and in participating in focus groups these middle managers were not only providing a deep knowledge of their immediate context but they were also encouraged in talking about how and what they do in practice, providing us with a rich set of activities underlying their discursive sensemaking competence. To understand performance we need to go beyond observation to understand it as researchers rather than just an audience, by gaining access to some of the backstage and not just the overt. ${ }^{[1]}$ Needless to say, we were as researchers engaged in the co-construction of their discursive sensemaking when conducting narratives of practice and focus groups (see Balogun et al., 2003; Rouleau, 2010). Yet the data were originally gathered for different research projects providing protection from charges of researcher bias.

Since the stories focus on individuals and their strategizing activity in situations of change, this is consistent with the study of middle managers and their discursive competence as part of the accomplishment of their strategic roles. To study middle managers' situated sensegiving activities in strategic change it is necessary to be located at the micro-level in order to see how it works in action (Jarzabkowski et al., 2007; Rouleau, 2005). Obviously, it is also critical to examine the activity of the middle managers in context. Therefore, whilst each of the research projects affords the opportunity of developing many middle manager stories in different organizational contexts, for purposes of comparison, each author focused on one of their organizations, for which they had two middle managers providing data of appropriate richness and depth in terms of both actions and their reflections on those actions. As is the case for all respondents, the ones drawn on here revealed a differential ability for self-reflection. The authors then developed four stories describing each middle manager experience, written to locate their actions within their context of operation. The four stories are presented in the next section as shorter vignettes.

As is common with qualitative research, the stories were analysed through repeated iterations between theory and data (Langley, 1999). The starting point was to seek to understand the linkages between interpretation and action, broadly defined as sense reading and sense wrighting, consistent with a sensemaking perspective. We used the metaphors of 'reading' and 'wrighting' to remind ourselves when analysing our data that we were seeking to understand how our middle managers accomplished this activity and 
not just identify what they did, and to push ourselves to deepen the level of our analysis. This was consistent with our focus on elaborating existing theory rather than developing it, and on identifying the pixel details of the middle manager strategic work. Whilst it was not possible to specifically extricate the cycles of interpretation and action, it was possible to establish an understanding of what the middle managers did and said and why they $\mathrm{did} /$ said things this way. The 'what' gave the action and the why the interpretation underpinning action.

This analysis led to the development of the first part of the framework shown in Figure 1. We were able to identify two sets of interrelated discursive activities used by middle managers to enrol others to their cause that we label 'performing the conversation' and 'setting the scene'. 'Performing the conversation' relates to the multiple ${ }^{[2]}$ interactions middle managers engage in through formal and informal conversations with their peers, subordinates, superiors, and customers or other stakeholders, to draw others into their agenda. As we say above, we already know that it is the daily conversations with these others that constitute the privileged vehicle for developing interpretations of what change is about. Thus we use the label 'conversation' to be consistent, yet also noting that conversation has a particular meaning since 'the practical effect of conversation is to establish a basis of action and to maintain the coordination of members' (Taylor and Robichaud, 2004, p. 397). We add the label 'performing' to invoke the often deliberate, conscious nature of what was being done to influence, and to capture the ongoing orchestration of an event as it unfolds, and that extends 'performing the conversation' beyond what is captured within 'issue packaging' (Dutton and Ashford, 1993; Dutton et al., 2001).

The label 'setting the scene' extends beyond the using and developing of networks to refer to what is done to set up the context for, background to, and occasion for the conversation performance. It also includes future oriented activities such as building a personal image as a partner or a spokesperson to facilitate subsequent scene setting and conversation performances. When conversation performance is put in the context of setting the scene it emphasizes the relational aspect of middle manager sensemaking in which we are interested.

The two dimensions together correspond to what middle managers do in a situated performance. From examining what the middle managers said about their activities to do with 'performing the conversation' and 'setting the scene', we were able to see that the actions were based on particular ways of acting and interpreting which went beyond knowledge of language. The middle managers were certainly mobilizing particular types

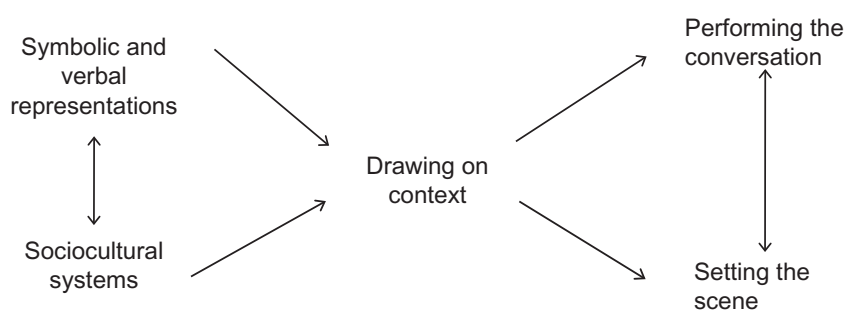

Figure 1. The discursive activities of middle managers in strategic sensemaking 
of language to trigger linkages with taken-for-granted and accepted ways of doing things in the organization and build acceptance of their position from others. However, the middle managers were also mobilizing the social and cultural systems to determine who they should be having the conversations with and when, or in other words what forum and format. This was not straightforward as they were also relying on the mobilization of this knowledge to determine the configurations of the different stakeholders they needed to involve. For example, they might need to use different symbolic/verbal representations with different stakeholders, which fed into the format of the conversations and the constellation of stakeholders present. Thus we label the third interpretive element of Figure 1 'drawing on the context', where context consists of symbolic/verbal representations and social/cultural systems, such as an emphasis on bottom-line performance to the exclusion of virtually anything else, or power dependencies, or social networks. This dimension of our analysis links to the need to know more about middle managers' ability to influence through unpacking the nature of knowledge they draw on and mobilize to develop situated performances.

The next section of the paper presents the four middle manager vignettes drawn from the two research projects. For each study the context is explained first, and then the two middle manager vignettes from that study are presented to illustrate how we derived our framework presented in Figure 1. (Table AI in the Appendix presents a detailed analysis of the quotations from the vignettes to show how performing the conversation and setting the scene are underpinned by symbolic, verbal, and sociocultural systems.)

\section{VIGNETTES OF MIDDLE MANAGERS AGTING DISGURSIVELY WHEN MAKING SENSE OF GHANGE}

\section{Restructuring Radio-Canada: The Cases of Mary and Robert}

The first database involved data on middle managers' work life gathered through a research project designed to better understand the transformation of their professional identity in the context of organizational restructuring (Rouleau, 2010). This vignette has been built with the narrative of practices of Mary and Robert, two middle managers involved in the restructuring of Radio-Canada. Radio-Canada is the French division of the Canadian Broadcasting Corporation, mandated to broadcast Canadian culture. At the beginning of 2000, this public trade-unionized organization had to face a new competitive environment characterized by deregulation and revolutionary technological change. In a context of government budgetary cutbacks, the top management team wanted to reduce production costs, transform the hierarchical bureaucracy into a more flexible organization, and privatize part of the technical operations.

At the heart of the restructuring was Radio-Canada's plan to reorganize the Technical Production Directorate. Historically, Technical Production had to have on hand the human and technical resources necessary to meet the Programme Production Directorate's requirements when they arose (which was costly and inefficient). With the cutbacks, despite historical rivalries and differences, the two directorates now had to jointly plan their activities. Mary and Robert were two middle managers in charge of the transfor- 
mation: Mary as manager of this unit (TV sector), and Robert as coordinator of technical services (information sector). In order to succeed in this difficult task, Mary and Robert needed to draw on their discursive competence to make sense of these internal transformations and bring people into their own agenda (see Table AI).

\section{Mary}

Mary had been working at Radio-Canada for nine years. She rapidly became a middle manager in the TV Programme Production Directorate. In the restructuring, Mary was promoted to the role of Technical Production Manager (General TV sector). The sector has over 500 employees and was historically managed by people with technical backgrounds. Radio-Canada's top management appointed Mary, a person associated with Programme Production, to this role to facilitate change. What saved Mary in this new role was her ability to find the right words to talk to technicians and in the right way (performing the conversation) and to build relationships, networks, and coalitions that provided her with credibility and knowledge that could be used to compensate for her lack of technical expertise (setting the scene).

One of her mandates was to make the production studios profitable, which among other things involved reorganizing technicians' assignments. Mary knew nothing about the technical side of things yet was in a directorate where credibility is based on the degree of technical knowledge.

When I arrived, they said, 'What's she doing here? She doesn't know anything about technical production.' I knew nothing about it, I came from Programme Production. The first think I did was put my cards on the table, saying, 'Listen, I'm not here to repair the camera downstairs. I'm here to structure, to organize things, and I want it to work because we've had budget cuts for 5 years now, and with the retirement boom, there's almost no one left with any experience. (M1)

Her appointment might have clearly reflected the new direction that Radio-Canada wanted to take in order to make a big change, but was not an easy task.

We had to start all over, it was chaos. In those first meetings or when people came to see me in the beginning, I listened to what they had to say to me. I used that to find the right words to get the message across. If someone talked to me about his job, it was the job we talked about until he understood that we could look at the problem from another angle. (M2)

Not only did Mary prioritize her relationships with the people working under her supervision, she also based her management on transparency and integrity.

I like to deal with people. I always listen to what they have to say. However, with me, they know things are clear. I never say something for nothing, and I expect them also to tell me the truth. I can get angry as well. (M3) 
Moreover, in the restructuring she devoted a large part of her time to writing reports of the meetings she attended.

Even though I had lots of meetings and I solved lots of problems in a day, I spent at least 10 to $15 \%$ of my time making summaries of my production meetings. I showed them to lots of people, everyone had to be part of it. (M4)

Those quotes reflect how Mary tried to give meaning to the change and influence the technicians when she was performing her first conversations with them. From the start, she admitted her weaknesses and replaced the technical expertise discourse with a discourse of change crafted in accordance with the problems that the technicians were facing day-to-day (M1). In so doing, she pragmatically constructed a rallying discourse by listening to people and talking to them through language and verbal representations that directly targeted their problems (M2, M3). Simultaneously, she was able to attract the attention of the technicians in their daily interactions by drawing on her sociocultural knowledge of the organization. For example, she positioned herself as one of them rather than as spokesperson for the directorate, thus presenting herself closer to the historical culture of the Technical Production Directorate (M1). The importance of being clear and transparent is linked to the fact that historically the management message used to be ambiguous in this public organization (M3). By using reports to arbitrate conflicts between the Technical Coordinators and the Programme Production people, not only did she draw on the bureaucratic nature of Radio-Canada in order to little by little consolidate some compromises between the two groups (M4), but she was also setting the scene for each meeting (M4). So to speak, she has the capacity to perform a peoplefocused management style, almost a maternal one, while using a firm attitude suited to a male-dominated world (M1, M2, M3).

Mary's ability to 'get the message across' was rooted in the fact that she regularly visited the sets of the TV shows to develop and maintain good relations with others. Thus, she says:

I go and ask, 'How are you?' I say, 'Hello' to everyone, and after the show is over, I come to see if everything was OK. Bosses don't usually do this but it's essential. (M5)

While she was learning how to make a TV show through casual discussions with many different people, she was also setting the scene for the following events related to the change. These informal meetings enabled her to get to know the employees, who to contact in case of any problems or emergency, and at the same time gave her credibility when she was in negotiations with them. By taking a lot of small actions to ensure that she was surrounded by the right people if needed, Mary was able in large part to overcome her lack of technical knowledge and facilitate the change.

You have to go looking for people, the right people, people who know the field, people you can trust and who will trust you ... Since I had been going to the sets for years, I knew the cameramen and the technical guys. When I needed advice, I went to see them. (M6) 
Not only did Mary know how to surround herself with people who had the technical knowledge but she also knew who to turn to for the administrative knowledge.

There's also Francine who helped me, she's an administrative assistant who's been at $\mathrm{RC}$ for more than 25 years. She helped me a lot by giving me cues like 'be careful about such and such thing'; 'that person's been in the department a long time'; 'you can't say it like that, you'll get in trouble'. Without knowing it, she helped me a lot. (M7)

All the previous quotes demonstrate that Mary knows that to make sense of the change experience matters. By being present she increased acceptance of herself by others and got to know those who she could ask for an opinion or advice when needed.

The same is true of the networks she cultivated with the members of management. The person who appointed her had worked with her previously and knew her well.

I was not alone making all these changes. I worked in a team with John [her immediate supervisor]. We complemented each other like a couple. He knew the collective agreement that had to be renegotiated and he was on good terms with senior management. I knew how to make a TV show; I knew how to sell my ideas. He knew the people in Toronto and even coast to coast. I knew several people in the corporation by their first name. Between us, we had everything we needed. (M8)

In addition to restructuring the Technical Production Directorate internally, Mary cultivated her collateral contacts, for example, to make the production studios profitable. As secretary of a communication and broadcasting executive's association, she set up a studio rental service for private producers.

Now Radio-Canada is no longer only self-contained, we're also in production companies, and that's a big network in a small world. (M9)

These comments show that Mary knew that to make sense of the change at RadioCanada she had to set the scene outside of the organization as well as inside, by building networks and coalitions internally and externally in order to make the change to a profitable operation. Her privileged contact with her boss facilitated the actions she deployed internally, and she achieved the partial privatization (letting private producers hire the studios) of technical production by being involved with other stakeholders belonging to the broadcasting association. In other words, through her engagement in this extra-organizational forum she set the scene for influencing change at RadioCanada, and in turn was also participating in the transformation of the more general Canadian broadcasting environment.

Simultaneously, her ability to set the scene is discursively anchored in the sociocultural frameworks she belongs to. By seeing herself and her boss as a couple, she pragmatically refers to the sexual gender division of the organization (the Programme Production is female dominated while the Technical Production is male dominated). By using the expression 'coast to coast', Mary is expressing the idea that to make her way in the 
organization, it was important to be in contact with the English-language section, the $\mathrm{CBC}$, where the real decision-making power was. Finally, in her last comment, she indirectly suggests that privatization is based in part on Radio-Canada's ability to work in and renew the extra-organizational networks.

\section{Robert}

Robert had 12 years experience at Radio-Canada. Some years previously, he had been in charge of organizing the technical team for the new specialized news and information channel (RDI) created at the end of the 1990s. In the restructuring, the news production staff of the general television sector ('channel one') had to be renewed. The job was entrusted to Robert who was returned to his previous duties even though his title changed. He became coordinator of technical services for the channel, supervising approximately 50 technicians. Due to the budget cuts, he was also put in charge of the technical equipment.

Robert's team had a bad reputation and was experiencing serious problems with absenteeism. Within the organization, it was seen as a 'little mafia'. The technicians, especially the most senior and the most experienced, used their professional expertise against the establishment, even 'terrorizing' the people who worked on news show content (journalists, producers, etc.). With the budget cuts, Robert had to streamline the work and job assignment processes while ensuring the flexibility needed for the unpredictability of televised production. In addition, he worked to reconcile technicians and programme production employees.

Robert had his own management style, largely based on flexibility and the importance of talking together. He says:

In my family, we always had renters. I bought my first house at 22. My first management experience was with my renters. It's not the same but that's where I learned to deal with people, learned the respect you have to have for others in what you say and the way you say it, I learned that there. I learned you had to be accepted by people. When someone's unhappy, I learned you can't fly off the handle, you have to deal with people. (R1)

Along with the technical expertise, Robert was aware that to get anything done he had to be accepted by the technicians. He says that his principal management tool was a deck of cards.

People come to see you, talk to you, you get to know them. Then, when they come to ask you something, you know if it's credible or not. And when you give them something, they owe you one. (R2)

Theses excerpts show how performing the conversation stands on his capacity to speak respectfully by using the right words in the right ways. Moreover, his individual capacity to make sense of the world through conversations resonates with his previous experience of dealing with people acquired in another context. By playing cards, he is also setting the 
scene for the multiple conversations in which he negotiates with technicians. This specific way of managing is inscribed in the group's sub-culture (card game as an embodiment of the mafia-like activity).

Robert is also known for his frankness, particularly when talking with his supervisors.

Since we're in the communication business, we ought to talk to each other from time to time. They know me, I'm not shy. I'm also capable of saying what I have to say even if it's harsh sometimes. Sometimes, you have to make waves to be heard. With the voice I've got, it helps. (R3)

By saying out loud to management what everyone was thinking (and using irony to subtly denounce the fact that management was also partly responsible for the prevailing problems), Robert positioned himself as the spokesperson for the technicians he supervised, which increased his legitimacy in his unit.

Robert's legitimacy was also the result of the network of internal contacts he had throughout the organization.

Of course there's the official network, we know who's in charge of what. But the informal networks are often more efficient and that's not written anywhere. Without these networks and the knowledge of these networks we can make assignments that make no sense and will cost a lot. (R4)

The composition of the technical teams was a key issue in Robert's work that required him to know 'who' could work with 'whom' on the same show. In addition, the production of news and information shows is unpredictable, creating daily technical problems that have to be solved quickly.

I worked at several different areas in the corporation as a technician, I know the workings of each area very well. When we had a problem, I was able to say to the guys, 'Call here', 'call there', and 'call him', and they'd get on the phone and it would be solved. If you want it to work, you have to call the people you need directly, it's faster. (R5)

In these comments, Robert clearly expresses the need to speak to people directly and to know who to get in touch with in case of problems. In order to do so, his previous experience in different services gave him the possibility to set the scene for being able to quickly make the right moves.

In his narrative of practice, Robert demonstrated his ability to mobilize internal networks in a crisis by proudly relating how he succeeded in organizing a production team during the 1998 ice storm. In a city covered in ice he had to find technical employees to do the outside broadcasts:

My boss, the Production Manager had spent a day trying to get people. He sounded like this on the phone: 
Production Manager $=$ Hello, this is P. L., the Production Manager.

Technician $=$ Who's that $\ldots$. What do you want?

Production Manager $=$ Can you come in please, we need people.

Technician $=$ Nope, not available.

I said: 'Never mind, I'll call them, I know them, I'm close to them.'

Robert: Hi, how are you? Have you got a fireplace, enough wood? . . . Listen, we're in a bind, do you think you could give us a hand for a few hours?

Within 15 minutes, I put together a team. I know just about everyone here. I knew who I could call. I knew who was more or less in the power outage and I knew how to convince them to come in. (R6)

This illustrates Robert's relational approach, which contrasts with the senior executives and shows the importance of knowing 'what' to say (performing the conversation) and knowing 'whom' to call in an emergency (setting the scene) and how these two activities are intertwined in practice. Instead of using his authority as a manager as the production manager did, he first began by finding out how the technician was coping in the ice storm (using verbal representations meaning something for the interlocutor). Then, he appealed to team spirit and used the difficult situation to convince the technician to come to work. He draws on his sociocultural knowledge of the technician's personal situation (where he lived, if he owned a house or rented, which was important in a winter weather disasters), and called the ones he thought could come in instead of religiously following the seniority list as the production manager did.

Beyond managing problems and unexpected events, Robert worked daily to create meanings around the new vision of partnership between Technical Production and Programme Production, both in his team and with his colleagues.

The guys got on board when I stopped saying, 'This group is responsible for this, that group is responsible for that.' Since then, I've tried to get my people to say, 'The service was given; Radio-Canada gave the service.' You have to move toward positions that bring unity. You have to work together, tell yourself that we're all on the same wavelength. (They'd be happy to hear me say that upstairs!) (R7)

He also made this effort with colleagues from Programme Production.

One day, I said to a producer: 'That cameraman you want, I can't assign him to you' ... She got back to me in an email saying, 'You know in my collective agreement I have the right to choose my close collaborators.' Rather than saying, 'OK, let her decide herself if she's not happy' like it used to be done, I had to meet the person, talk to her, reassure her, tell her that we'll provide someone just as competent, make her understand that if she works with us, it will help her on the set, it will help everyone and no one will lose out. (R8) 
These quotes demonstrated that Robert understands that in order to change things, the meaning and verbal representation of the message also has to change, and that he himself has to set the scene differently with the Programme Production by changing his own way of managing the relationships with people from this direction. In both cases, Robert draws on his general knowledge of his unit and of the Programme production to convince people to change their minds and in so doing he is giving practical meaning to the change.

\section{Delivering Change in a Multinational: The Cases of William and Jane}

The second research project involves longitudinal real-time tracking of change projects and the middle managers assigned implementation responsibility (Balogun et al., 2005). The organizations involved were part of a collaborative research consortium and came from sectors as diverse as pharmaceuticals, consultancy, and automotive. The change initiatives were equally diverse, including post-merger integration, exploitation of acrossbusiness synergies, and implementing more integrative structures. The boundary spanning practices of the middle managers involved were explored in context to enable an appreciation of the contingency of their emergence and development. Here, we develop our vignettes from two individuals in just one of the organizations called Engco.

Engco is a multinational engineering company, with several diversified divisions reporting into a corporate centre located within the UK. Traditionally, the divisions operated as independent silos. Each division acted autonomously of the others rewarded for and only answerable to the centre in terms of performance. Thus Engco was running change projects to create cross-business synergies between these diverse business divisions as part of a more general move towards synergy development. Two individuals William and Jane - were involved in these projects. Engco provided no central mandate for these centrally initiated change projects, despite the fact that the traditionally autonomous divisions typically resisted such centre-led changes. To succeed, William and Jane needed to use their understanding of the context to engineer divisional support for projects that would otherwise fail (see Table AI).

\section{William}

William, the group head of remuneration and benefits, was examining across business practices in areas such as pensions with the aim of creating common procedures and using common providers where possible to reduce costs. Despite the fact that he was relatively new having joined Engco within the last year, he observed:

There is a way of thinking that is probably consistent, how to do things with the least amount of resources possible. Bottom line, cost focused is probably the cultural identity.

I think there is a mistrust of anything that is not money, money, money . . . You have a group of accounting people and a group of engineering people who want very quantitative things. Cash and profit are things you can identify. (W1) 
He understood the need to bring the divergent divisions together through a message that cuts across interests.

It was very clear even back then that we don't have a central mandate . . it's like 'no no divisions are very autonomous', so we've really put a lot of effort together in putting an attractive package together, a lot of analysis that says here's a really really good way to do it, here's how much you would save if you do this and this ... that kind of thing ... So we're getting that group together then presenting to our HR folks, getting them aware of it and our next phase is executives. (W2)

When performing conversations, he was also aware of the need to provide to those he worked with a means of 'selling' the message, not 'telling' given his lack of mandate.

They have to believe it because they have to sell it, and it is not a pleasant message for them to hear. So we start off by saying we did good last year and made a lot of progress but now things are tougher we need to take another step. I didn't just say we have to save $\mathrm{x}$ million, it was more selling than telling, but not sugar coated. Profit is up, earnings down so we have margin issues, it is business reality. (W3)

When performing conversations, William regularly refers to things such bottom line, cost focused, balance sheet, margin, money, cash, profits, to appeal to the 'money men' nature of Engco. He also packages messages through quantitative representations and by being positive. Through using appropriate words and crafting a message, he is able to link into the shared interests of the divisions (the bottom line) and to link his agenda to the perceived need for change in view of external trends ('margin issues', 'business reality'). According to him, it is by being consistent with the organizational values and repeating his messages in the same way that enables him to transcend the divergent interests and identities across the divisions.

William also consciously staged conversations. He wanted to get non-financial objectives included in the reward and performance assessment of senior managers so that he and others implementing central initiatives could use such an objective system to encourage participation, but he also knew that the remuneration committee was not 'that thrilled' about making these sort of changes and it would be a 'tough sell'. Thus he used his connection to the board through his boss to take his case for a change in the remuneration systems to include some non-financial objectives (10 per cent weighting on a management by objective component) alongside the financial ones to the board preparing a presentation designed to appeal to them.

I put together the proposal and went to the board meeting and presented . . they almost closed me down before I got to my slide. I said, 'Excuse me, if we could just go through the logic before you make a final decision'. So, we did ... (W4)

As such, some conversations were not directly related to what he wanted to do, but were needed to subsequently enable him to do what he wanted to do. He wanted to 
position himself as working in a business partnership with the board rather than just being there to 'report' by linking what he did to their concerns.

I think what I am doing now is a lot more connected to the business . . because of the implications for the balance sheet. I am in the boardroom a lot more than I was before. It is a different role, rather than just reporting on our results . . this is more about how we reduce our risk and liability, what are the cash flow implications, etc. It is much more business focused. (W5).

In these quotes, we can see that not only does he know how to talk to others but he also knows that you need to be supported by influential people (his boss). He knows that adopting a self-confident attitude and working within the context of board meetings is important for sensitizing board members to his agenda. Not only did it allow him access to the board, it also transformed the way the members saw his role, reinforcing his position for future negotiations with them. His ability to perform the conversation and set the scene for future ones was informed by his understanding of the resistance context and the dynamics of the board.

William knew the importance of getting different networks to support his work and how to set the scene for different conversations to do this. He understood the need for participation, for example, to create a joint decision making process with the divisions which overcame suspicion of the centre.

... there was a lot of sort of mistrust at the centre. Just being very open and repetitive about it's not a mandate we want to develop a logical framework and have a process for doing this is really helpful. As people would have said oh OK so it is transparent you're not trying to do something to us, we're making decisions. So having them participate and sort of leading them to a rational conclusion that they are going to buy into. While looking through some of the political turf issues, just within the group because of course they don't want to loose their positions and they want to protect their turf and do things their own way ... so that's been the biggest hurdle. (W6).

In addition, through forming personal relationships he developed networks that he could use to perform conversations on his behalf.

Having done a lot of travelling last year and meeting a lot of people has helped so I don't have to do so much of that anymore. I can now rely on one part of the network and get them to spread it out. I reinforce it a bit but I don't have to go and communicate to every single person in my network. (W7)

He was relatively sophisticated about the way he would set the scene for conversations. To reach individuals he has an appreciation of other peoples' agendas.

I guess you try and find out what is in it for them . . . Try and find out how reluctant they are. Are they reluctant because someone else is? I had this issue in the US with one of the guys who was very bright and capable but very resistant and it turned out 
that it was his boss who was resistant and not him. So then I had to find ways to appeal to his boss and sell the message as if I was talking to his boss but through him. (W8)

He has a policy of working with people individually when they are resistant or if they have personal power to get them on his side before calling individuals together to progress things as a team. He would also try to build linkages when he first met people through using 'icebreakers', drawing on what he knows about their interests. For example,

a shared Welsh ancestry ... knowing the latest rugby scores. (W9)

He had been known to do things such as position experts in the audience to be called on for support.

I also had an outside physician in the audience who was talking about health care issues because if they can hear it from a different perspective in terms of how they might go about achieving this ... (W10)

He had also employed tactics such as 'good cop, bad cop' with himself as the bad giving the nasty message and one of his managers as the good being more consultative. Furthermore, William's boss had a dotted line to all the HR directors and to the CEO, so William used these chains. In addition, as William developed his networks, he widened his access to include the bosses of his clients, which enhanced his access to decision makers and his role context.

\section{Jane}

Jane was running an innovation project to encourage the development of new business ideas from the divisions. She had less board access than William and was therefore more reliant on her project sponsors to facilitate support. However, like William, she uses her contextual understanding to gain support for her project.

As with William's initiative, there was no formal mandate forcing businesses to engage with Jane's group and take up the ideas - it relied on individuals (mainly divisional coordinators) being released to take things forward - and that could be counter-cultural. And Jane knew this.

It's a very delicate balance because the divisions within Engco are all powerful, they have all the resources, we have no resource. So a lot of it is about persuasion really, saying to them 'we are trying to make sure that across the whole of Engco we have a good pipeline of ideas in all of these horizons'. (J1)

In this context, her role was to oversee that process and to work with those local facilitators and the different review groups. To achieve this, she developed a range of different ways of performing conversations to be in close contact with them and to create a group feel. 
Well there were a number of mechanisms to sort of keep them together ... there was the monthly audio conference, and then two or three times a year actual physical get together which also happened to overlap with other meetings ... so at night you would have a dinner with everybody ... that was a way of basically trying to use the group to develop the process. (J2)

However, Jane also knows that performances do not have to be verbal and face-toface. Conversations can be performed in different settings to provide multiple ways of reaching networks. Whilst Jane saw the face-to-face meetings as very important, she also used monthly audio conferences, and one-to-one phone conversations, and many other mechanisms.

We had other things like newsletters which we would send out to divisional co-ordinators but also to all of our local facilitators to put it on notice boards . . . this company here has just had a launch and these people ... here are the prizes they have won. I would email them, either individually or collectively on a number of different issues and a lot of it was done by phone call and just personal contact ... I would go and talk to them. (J3)

In performing conversations, Jane recognized the 'balancing act' and that her point of persuasion was encouraging the organization to 'think about the future' through a 'pipeline of ideas' and through such means 'drag the organization away - even one degree - from its straight and narrow operational performance focus'. She persuaded senior managers by, for example,

parcelling the future of her projects in order to sell its short term benefit, or nurturing ideas to identify who to sell them to. (J4)

In other words, she was constantly combining the what of the conversation (through how she parcelled benefits), with the who (identifying who might be interested), the how, and the when (in terms of timing), showing the tight linkages between performance and scene setting. She also recognized the divisional and silo based nature of the organization, and the need to generate a flow of conversations that created alternative connections. She used special scene setting in the form of a roadshow, in which the coordinators had to perform conversations with each other to make it work, without her.

We organized a roadshow recently, which basically is just five big black cases, it opens up into a big stand ... and we deliberately have organized it so that it is like a hand me on type of activity, so we sent it to the first location in a given country. Gave everybody who was to receive it a timetable and said, right, get on with it, use whatever transport links you already have, just do it. (J5)

Whenever Jane wanted someone to do something she was in competition with the divisions. There was a constant battle 'releasing resources and finding funds', and thus she had to influence and have conversations at multiple levels. 
Well I know the divisions are working hard to deliver today's results but we're trying to put some things in place for tomorrow ... everything now is very divisionally focused and if they don't see the immediate benefit it probably won't happen, it certainly won't get funded. (J6)

She added:

The power that you have is that you have the steering committee and some of the main board directors and senior guys from the divisions on that committee, therefore you are acting with their goodwill . . . but at the end of the day if the division decides they are not going to work on any of the new ideas there is not a lot you can do. (J7)

This last quote clearly again shows the link between performing conversations and setting the scene to appeal to and integrate particular networks. Due to the nature of the centre-division relationship, Jane has to rely on others to promote the innovation project, and in particular to draw on senior management sponsorship when it is available - such as the innovation summit.

We had an 'innovation summit' last year and invited about 100 people who were involved in the process to come to Cardiff and our CEO turned up and gave a speech and it spread like wildfire around the place. All of a sudden everyone comes back much more energized. (J8)

She also drew on her personal networks, showing the importance of performing conversations to create and maintain these networks so they were there when needed.

I found that helped enormously (using own personal networks). If I had a problem I'd ring them up, need a bit of help, and from my own personal benefit that has been very supportive. (J9)

\section{DISGUSSION}

This paper seeks to explore middle manager strategic sensemaking through two questions: (1) how the sensemaking required as part of a strategic role is discursively put into action by middle managers; (2) through which activities the discursive competence is enacted by middle managers. We use the term 'discursive competence' to refer to middle managers' ability to knowledgeably craft and share a message that is meaningful, engaging, and compelling within his/her context of operation through discursive performances. We use this term rather than discursive ability (Maitlis and Lawrence, 2007) to emphasize the fact that our findings show influencing to move beyond the skilful use of language.

Our findings show that there are two discursive activities, performing the conversation and setting the scene, that are central to the way middle managers enact sensemaking to accomplish their strategic roles, and that are underpinned by the middle managers' ability to draw on symbolic and verbal representation and the sociocultural systems they 
a) Context specific language, terminology, metaphors

b) Context specific representations such as quantitative analysis, use of logic, presentations, reports

c) Means of demonstrating legitimacy, integrity, respect, transparency

d) Adoption of relevant images for influencing
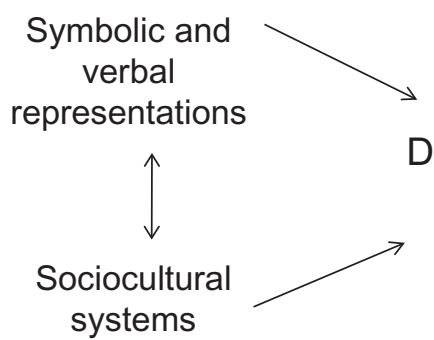

e) Awareness of identities, interests and points of resistance of different stakeholder groups f) History of people and groups in the conversation

g) Means of displaying appropriate emotions and relational attitudes

h) Awareness of context specific rules of engagement
1) Knowing what to say to each stakeholder group (e.g. linking agenda)

2) Using the right words and phrases

3) Crafting and diffusing the appropriate message

4) Staging the conversations (e.g. using relevant social rules of engagement/protocols, timing use of expert others in meetings)

5) Relating to others (e.g. using first names or not, putting people at ease by asking advice)

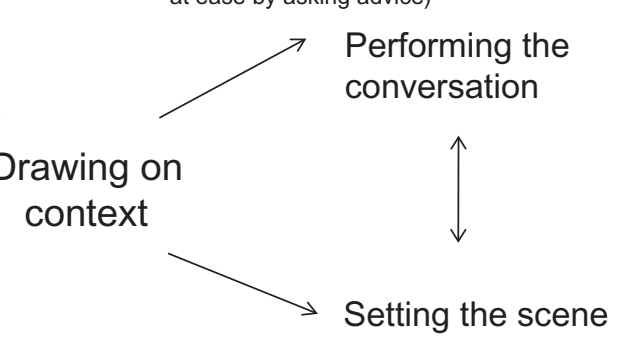

\begin{abstract}
6) Knowing who to target and who to use to influence
7) Bringing the right people together

8) Identifying the right media, formats and forums for different stakeholder groups

9) Setting up the conversations for different stakeholder groups (e.g. appropriate timings and contacts, appropriate packages to use, etc.)

10) Building conversations and networks that can be used in future

11) Building personal image, e.g. as seller or partner or spokesperson
\end{abstract}

Figure 2. Strategic sensemaking and middle managers' discursive competence

The numbers and letters cross reference Figure 2 to Table AI.

belong to. As part of our analysis we build a repertoire of detailed activities and the underlying contextual knowledge from the vignettes (see Table AI). This in turn enables us to identify sub-sets of activities and knowledge through which the middle managers' strategic sensemaking is discursively performed as they attempt to draw people into the change (see Figure 2). Figure 2 allows us to argue that middle managers' strategic sensemaking and sensegiving is embedded and constituted through the middle managers' ability to order and deploy their knowledge of the situation through the appropriate words in a specific context in order to influence others.

As Figure 2 and the vignettes illustrate, 'performing the conversation' refers to the way that middle managers in diverse circumstances are able to 'craft' and 'diffuse' the messages they wish to get across to others to influence the recipients in the way desired; they are able to use the right words, the appropriate metaphors and symbols. For example, William and Jane use language such as 'margin' and 'cost', to link to the performance, bottom-line culture of their organization and therefore mobilize people to their cause. In some ways, 'performing the conversation' refers to a constructive verbal exchange which attempts to reconcile divergent demands and interests coming from upper and operational levels, or from different parts of the same organization. In these conversations middle managers create meaningful opportunities through language to draw people into the change by using words connecting with their issues and interests. However, our findings on performing the conversation move beyond language use and what others call 'issue packaging' (Dutton and Ashford, 1993; Dutton 
et al., 2001). Figure 2 includes activities to do with 'staging the conversation' and 'relating to others'. These activities relate to the need to conduct different elements of a conversation as the performance unfolds. Examples include William's placing of experts in an audience and then drawing on their expertise opportunistically at appropriate points, or Mary putting someone at their ease by asking their advice. Performing the conversation therefore goes beyond using the right words and phrases to the conduct of the entire conversational event, which cannot be scripted in all elements as it has to allow for improvisation based on the way individuals present are responding. This finding suggests that:

Proposition 1: Middle managers' strategic sensemaking is more likely to be influential if they are able to anticipate and improvise around language and social cues that connect with others' interests.

'Setting the scene' refers to the capacity of middle managers to bring people together around a change project in order to make sense of it and build an alliance working towards the change, even if it is for different reasons. Specifically it refers to the knowledge of who to contact, who to bring together, and who to use to influence things. In strategic sensemaking, middle managers have to reassemble their subordinates and their peers (and at times maybe senior managers) around their cause and enrol them. In order to do so, they also need to mobilize the appropriate network formats and forums. For example, by surrounding herself with the right people, Mary was able to overcome her lack of technical knowledge. The middle managers activated their networks to make different meanings and interests mutually compatible around the change. It also provided them with legitimacy for acting as change agents.

However, 'setting the scene' is not just about the 'who' in terms of knowing who to engage with and draw in, but also includes the appropriate means to reach these people (e.g. one on one, phone call, meetings). It includes knowing how to set up the arena in which the conversations are to be performed. Setting the scene is then putting this into practice, e.g. issuing invitations to meetings, or getting an item put on a meeting agenda, or writing reports and discussing them with people, or inviting someone for lunch or to play golf, or 'bumping into' someone in a corridor. The range of activities involved here is broad. For example, Jane wanted her local facilitators to talk to each other, so she organized a roadshow that required them to have conversations in her absence. As such, the range of activities here goes beyond what others term the 'selling process' (Dutton and Ashford, 1993; Dutton et al., 2001), encompassing future oriented activities such as building conversations and networks/coalitions/relationships in preparation for future use, or building a personal image as a partner or spokesperson or ally that creates credibility when needing to gain support from others at a later date. Formalizing this finding, we suggest that:

Proposition 2: Middle managers' strategic sensemaking is more likely to be influential if they are able to identify, assemble, and mobilize relevant alliances through formats and forums that enable them to connect with the interests of these others. 
These descriptions of 'performing the conversation' and 'setting the scene' also show that these sets of activities are discrete yet connected through practice, since they discursively co-occur in a performance that has been stage managed among a particular group of people to deliver a particular effect. Once middle managers have identified how to get the attention of people by drawing on the right symbolic/verbal representations, they need to draw them in through different processes. The way they position things, the stage management of the meeting, their awareness of identities, interests, and points of resistance, all enhance conversations. Then the enacting of the conversations is the 'on stage performance'.

The way middle managers make sense of the change and influence others cannot be understood without taking into account the knowledge middle managers have of others (for example, their interests, personal stories, and loyalties) and their organizations (for example, the rules, routines, assumptions, and language uniting yet dividing those within). Middle managers not only mobilize specific verbal expressions and symbolic representations, they implicitly draw on their deep knowledge of organizational codes and sociocultural rules. When Robert called the technicians in order to urgently set up a team, not only did he find the right words in order to convince the technician to come to work, he also drew on his knowledge of the technicians' personal situations and the team's work learned through 'playing cards' with them. The verbal representations used by middle managers reveal more than they actually say. New managerial demands, such as the new pensions programme, have to be symbolically anchored in the internal rules and the way managers position themselves in these rules in order to create sense and influence others. Therefore, we suggest that:

Proposition 3: Middle managers' strategic sensemaking is more likely to be influential if they both have, and are able to invoke, their deep knowledge of organizational rules and sociocultural codes subscribed to by others.

The way middle managers symbolically make sense of the change cannot be understood without taking into account the manner in which they position themselves as they interact with others. When Robert was calling the technicians, he was displaying appropriate emotions and relational attitudes that demonstrated that he cared about the difficulties the technicians were experiencing. Therefore, behind the verbal representations the middle managers use and the sociocultural rules they refer to, they also need to display meaningful images according to their own personality that then contribute to their influence on others. This can extend beyond the way in which they interact with others to include specific role positioning. For example, William positions himself as a partner of the board engaged in a common endeavour rather than as a project manager who is temporally executing a difficult task. By symbolically constructing their position according to the complex set of power relationships they were facing, middle managers enhance their discursive ability of empowering others. Consequently, we suggest that:

Proposition 4: Middle managers' strategic sensemaking is more likely to be influential when they are able to symbolically position themselves in such a way that they are cognizant of the differential power, status, and situations of others. 


\section{Contributions}

Dutton et al. (2001) build on Dutton and Ashford (1993) to argue that in the context of issue selling, they find the sensemaking process to be more 'political and contextually embedded' than originally suggested. By studying middle managers in a wider range of change related influencing contexts, we confirm this insight but also, importantly, advance it. We develop the notion of discursive competence through a fine-grained and detailed understanding of how middle managers have influential 'conversations' to gain attention and action investments from not just senior managers but also peers and subordinates, throughout the process of change implementation. More specifically, we highlight the significance of not just language use but also the nuanced understanding of context underpinning the middle managers' strategic sensemaking, both of which have previously been recognized in the literature but not theoretically and empirically developed.

Existing middle manager research such as Rouleau (2005), Westley (1990), and Hoon (2007), and more general sensemaking research, such as Maitlis (2005) and Maitlis and Lawrence (2007), point to the need to understand not just the form of middle manager conversations designed to influence but also the language use within them. Sonenshein (2006) shows that two specific forms of language, the economic and normative arguments, are at the foundation of these tactics when issue selling. However, our focus on strategic sensemaking as a discursive competence enables us to go further, recognizing the necessity to move beyond specific forms of language to extract the discursive patterns that govern the set of activities through which middle managers practically accomplish their strategic roles. We first empirically demonstrate that it is not just language use, but the combination of language use in particular settings with particular stakeholder groups that allow middle managers to influence others. Second, by showing how language use is intertwined with the building of settings in which to use the language, we show that strategic sensemaking is enacted through language use overtime. Strategic sensemaking is practically embedded in a chain of discursive acts that transforms the chaos into local situated meanings. Performing the conversation and setting the scene are interrelated, which also suggests that the more narrow categories of influencing activities, 'issue packaging' and 'selling process', are probably more interrelated as dimensions than previously suggested (Dutton and Ashford, 1993; Dutton et al., 2001), with the choice of process in turn affecting packaging, and the choices dependent on symbolic/verbal representations and sociocultural systems. As such, it is hard to separate the use of verbal and symbolic representations from the sociocultural context. The two are interdependent as are the two discursive activities of performing the conversation and setting the scene.

Our research also builds on research which suggests that managers need to be politically able to carry out their strategic sensemaking (Balogun et al., 2005, 2008; Buchanan, 2008; Mangham and Pye, 1991). Our paper shows context to play a major role in understanding the political as well as the discursive dimension of sensemaking. The power effect in sensemaking whereby some voices have more impact than others in part comes from a manager's contextual knowledge, and not just formal role power. Gioia and Longenecker (1994, p. 380), for example, argue that 'symbols are the medium 
for both sensemaking and influence and these two processes are inextricably linked'. This research strengthens this argument, but shows how symbolic manipulation is enacted through practical knowledge of both the symbolic code in an organization and the sociocultural structure.

More explicitly, this paper connects sensemaking with a capability to act politically, to activate some sort of systemic power (Lawrence et al., 2005). It shows that to act politically middle managers need to be socialized within their context of action to understand the symbolic and verbal representations and sociocultural systems, but that this is not some abstract/cognitive understanding, since it is connected with and embedded in situated practice relevant to a particular context. Existing sensemaking research (Gioia and Chittipeddi, 1991; Gioia and Longenecker, 1994; Maitlis, 2005; Maitlis and Lawrence, 2007; Mangham and Pye, 1991; Pye 1995, 2002; Pye and Pettigrew, 2005) describes various performances and the need for contextual understanding to perform in a skilled way, but it does not unpack the detail of that contextual understanding as this paper does to show that the 'craft' of sensemaking lies in intimate knowledge of the setting. In addition, others (Dutton et al., 2001) identify strategic, relational, and normative contextual knowledge as essential to influencing. Our framework suggests that although we can identify separate knowledge domains relevant to influencing activity, they are in effect interrelated in action in the situated sensemaking that occurs in a strategic role. We identify verbal/symbolic representations and sociocultural systems within what Dutton et al. (2001) refer to as normative knowledge. We also show that strategic and relational knowledge to do with saying the right things to the right people in the right way, should be understood in relation to these verbal/symbolic representations and sociocultural systems. In other words, our findings suggest that the strategic and relational are embedded in the normative contextual knowledge.

The findings related to the importance of context also illustrate the complexity of the sensemaking process. Drawing on multiway sensemaking as Maitlis (2005) did, this paper is one among the few studies that explores influence attempts not just from the middle upwards or the top downwards, but from middle to middle, from the middle downwards, and from the middle to the top. Our discovery of the importance of the setting building is probably due to this exploration of multiway sensemaking. It confirms that activities or moves involved in sensemaking will take different forms according to the stakeholder group to be engaged.

Finally, the research answers the calls from the SAP perspective to identify the actual activities managers engage in to accomplish their strategic work (Jarzabkowski et al., 2007; Johnson et al., 2003). The findings show that studying strategic sensemaking in practice is important because it provides a better understanding of the strategic middle manager role. By explicitly looking at the activities underpinning discursive competence it highlights the need to explore linkages between context, action, sensemaking, and the practical knowledge through which these are enacted, to appreciate 'knowledgeable performance' and 'effective action' (Orlikowski, 2002). Furthermore, this study adds to a growing body of research on middle manager strategic conversations within the SAP perspective. Hoon (2007) looks at middles trying to influence seniors. Rouleau (2005) explores middle managers influencing customers. Here we explore conversations to engage seniors, peers, and subordinates in change. In addition, other research such as 
Westley (1990), explores seniors trying to influence middles in conversations. Although these other studies do not specifically take the perspective we take here of middle managers as language based workers, we are starting to cumulatively build an understanding of the conversational activity in different settings. Thus, the paper also answers the calls for building cumulative knowledge on middle manager strategic influence and the underlying practical skills (Wooldridge et al., 2008).

\section{GONGLUSION}

This research advances what is known about how middle managers contribute strategically within an organization, showing the importance of discursive competence for a middle manager to be able to make an adequate contribution when asked to, or needing to informally, adopt a strategic role. It is quite possible that the findings extend beyond middle managers to more senior managers. Just as the discursive abilities explored here remain under-researched for middle managers, they are also under-explored for more senior managers (Fairhurst, 2007). We would argue, however, that it is equally valid to examine these abilities for middle managers given the strategic role they are increasingly acknowledged to play. Indeed, the four cases differ markedly in terms of change context (two different types of organizational restructuring) and managerial work (these four middle managers comes from different hierarchical level), and in terms of sociocultural frames they belong to (e.g. private and public organizations from two different countries). Despite these differences, the analysis reveals systematic similarities in the multiple ways these managers draw on context in order to perform the conversations and to set the scene when they are fulfilling their strategic roles.

To develop the research started here further, this study needs to be extended out from the implementation of change to other contexts where middle managers play a strategic role to identify if there are other generic discursive abilities in addition to the two that emerged here and extend the cumulative knowledge about them. Further research on middle manager discursive abilities in the situated sensemaking required as part of strategic roles should also try to theoretically advance the notion of discursive competence and test the framework through a bigger number of middle managers.

The findings do also have practical relevance. There are already calls for organizations to rethink the way they develop middle managers (Balogun, 2003; Floyd and Wooldridge, 1994). The research here emphasizes the importance of socializing middle managers into their context of operation to enable them to 'play the game', but also provides insight into how to appreciate which middle managers are likely to be more effective than others (see our propositions). We should acknowledge that those practised in the art of discursive competence may be the managers most able to contribute strategically. Knowledge of strategic frameworks and analytical skills may be important but are not the key differentiator. Furthermore, if we acknowledge that what separates an effective strategic player from a less effective strategic player is their ability to relate and engage in a way meaningful to those they seek to influence and lead, this in turn suggests that we need to teach strategy differently, taking a more discursive and less analytical approach. 


\section{APPENDIX}

Table AI. Activities repertoire and the underlying contextual knowledge (numbers and letters cross reference to Figure 2)

\begin{tabular}{|c|c|c|c|c|c|}
\hline & Performing the conversation & Setting the scene & $\begin{array}{l}\text { Symbolic and verbal } \\
\text { representations }\end{array}$ & Sociocultural systems & $\begin{array}{l}\text { Influence } \\
\text { direction }\end{array}$ \\
\hline \multicolumn{6}{|l|}{ Mary } \\
\hline M1 & $\begin{array}{l}\text { Crafts the message in } \\
\text { accordance with the } \\
\text { reality of technicians }(3)\end{array}$ & $\begin{array}{l}\text { Constructs a rallying } \\
\text { discourse (9) }\end{array}$ & $\begin{array}{l}\text { Uses a typical metaphor } \\
\text { of this directorate 'put } \\
\text { my cards on the table' } \\
\text { (see Robert) (a) }\end{array}$ & $\begin{array}{l}\text { Positions herself as a member of } \\
\text { the team (e) } \\
\text { Refers to the restructuring context } \\
\text { and its effects }(\mathrm{h})\end{array}$ & Downward \\
\hline M2 & $\begin{array}{l}\text { Uses what people say to } \\
\text { find the right words/get } \\
\text { the message across (3) }\end{array}$ & $\begin{array}{l}\text { Encourages meetings and } \\
\text { discussions with } \\
\text { employees (10) }\end{array}$ & $\begin{array}{l}\text { Translates the change in } \\
\text { the terms that goes with } \\
\text { the technicians' tasks (d) }\end{array}$ & $\begin{array}{l}\text { Uses the specific job context of } \\
\text { technicians in order to explain } \\
\text { what is the change about (h) }\end{array}$ & Downward \\
\hline M3 & $\begin{array}{l}\text { Listens to what people say } \\
\text { Deals with others in being } \\
\text { clear }(5)\end{array}$ & $\begin{array}{l}\text { Positioning herself as one } \\
\text { of them (11) }\end{array}$ & $\begin{array}{l}\text { Each thing said needs to } \\
\text { be clear and supported } \\
\text { (c) }\end{array}$ & $\begin{array}{l}\text { Has a people-focused } \\
\text { management style (maternal) } \\
\text { while using a firm attitude } \\
\text { suited to a male-dominated } \\
\text { world (g) }\end{array}$ & Downward \\
\hline M4 & $\begin{array}{l}\text { Makes people part of the } \\
\text { meetings' reports (4) }\end{array}$ & $\begin{array}{l}\text { Uses her reports to } \\
\text { reinforce the } \\
\text { compromises between } \\
\text { different groups with } \\
\text { divergent interests }(8)\end{array}$ & $\begin{array}{l}\text { Formalizes the content of } \\
\text { the production } \\
\text { meetings through } \\
\text { reports as symbolic } \\
\text { representations (b) }\end{array}$ & $\begin{array}{l}\text { Uses a bureaucratic } \\
\text { organizational rule }(\mathrm{h})\end{array}$ & $\begin{array}{l}\text { Downward and } \\
\text { upward }\end{array}$ \\
\hline M5 & $\begin{array}{l}\text { Says 'hello' to everyone } \\
\text { on a set (5) }\end{array}$ & $\begin{array}{l}\text { Creates ties by visiting } \\
\text { production sets before } \\
\text { and after filming }(10)\end{array}$ & $\begin{array}{l}\text { Uses the technical } \\
\text { language when visiting } \\
\text { the sets (a) }\end{array}$ & $\begin{array}{l}\text { Revisits the relation } \\
\text { boss/employees and } \\
\text { demonstrates interest and } \\
\text { openness towards technical } \\
\text { work }(\mathrm{g})\end{array}$ & $\begin{array}{l}\text { Downward and } \\
\text { collateral }\end{array}$ \\
\hline M6 & $\begin{array}{l}\text { Asks advice from } \\
\text { cameramen and } \\
\text { technicians (5) }\end{array}$ & $\begin{array}{l}\text { Surrounds herself with } \\
\text { people who know the } \\
\text { field, people you can } \\
\text { trust and who will trust } \\
\text { you (7) }\end{array}$ & $\begin{array}{l}\text { Demonstrates her trust in } \\
\text { people (c) }\end{array}$ & $\begin{array}{l}\text { Recognizes the importance of } \\
\text { technical knowledge }(\mathrm{g})\end{array}$ & $\begin{array}{l}\text { Downward and } \\
\text { collateral }\end{array}$ \\
\hline M7 & $\begin{array}{l}\text { Knows how to listen to } \\
\text { others to learn what to } \\
\text { say and how to say it } \\
\text { (1) }\end{array}$ & $\begin{array}{l}\text { Surrounds herself with the } \\
\text { right people } \\
\text { (administrative and } \\
\text { collective knowledge) (7) }\end{array}$ & $\begin{array}{l}\text { Uses cues and } \\
\text { organizational language } \\
\text { (a) }\end{array}$ & $\begin{array}{l}\text { Recognizes the organizational } \\
\text { context in which experience } \\
\text { matters (h) }\end{array}$ & Downward \\
\hline M8 & $\begin{array}{l}\text { Calls people by their } \\
\text { names (5) } \\
\text { Knows how to sell her } \\
\text { ideas (5) }\end{array}$ & $\begin{array}{l}\text { Works complementarily } \\
\text { with her boss in order } \\
\text { to reinforce her own } \\
\text { action power }(10)\end{array}$ & $\begin{array}{l}\text { Refers to the necessity of } \\
\text { knowing and using } \\
\text { union and technical } \\
\text { language (b) }\end{array}$ & $\begin{array}{l}\text { 'Coast to coast': Implies the } \\
\text { importance of ties with the } \\
\text { English-language division of } \\
\text { CBC (e) } \\
\text { 'Couple': Implies the gender } \\
\text { division of tasks in management } \\
\text { team (e) }\end{array}$ & Upward \\
\hline M9 & $\begin{array}{l}\text { Testifies that the change } \\
\text { happened (to the } \\
\text { interviewer) (3) }\end{array}$ & $\begin{array}{l}\text { Positions her organization } \\
\text { in a production } \\
\text { network }(10)\end{array}$ & $\begin{array}{l}\text { 'A big network in a small } \\
\text { world': uses the } \\
\text { metaphor of } \\
\text { privatization (a) }\end{array}$ & $\begin{array}{l}\text { Emphasizes the local character of } \\
\text { the French-language division (e) }\end{array}$ & $\begin{array}{l}\text { Collateral and } \\
\text { interface }\end{array}$ \\
\hline \multicolumn{6}{|c|}{ Robert } \\
\hline $\mathrm{R} 1$ & $\begin{array}{l}\text { Speaks respectfully with } \\
\text { people (right words and } \\
\text { right way of saying } \\
\text { things) (2) }\end{array}$ & $\begin{array}{l}\text { Knows that you need to } \\
\text { be accepted by people } \\
\text { (9) }\end{array}$ & $\begin{array}{l}\text { Uses the renting metaphor } \\
\text { to talk about } \\
\text { management (to the } \\
\text { interviewer) (a) }\end{array}$ & $\begin{array}{c}\text { Draws on cultural knowledge } \\
\text { acquired through previous } \\
\text { business relationships }(\mathrm{g})\end{array}$ & Downward \\
\hline $\mathrm{R} 2$ & $\begin{array}{l}\text { Evaluates the credibility of } \\
\text { demands (4) }\end{array}$ & $\begin{array}{l}\text { Creates occasions for } \\
\text { talking with employees } \\
\text { (playing cards) to create } \\
\text { future negotiation space } \\
\text { (8) }\end{array}$ & $\begin{array}{l}\text { Uses the negotiation } \\
\text { metaphor (a) }\end{array}$ & $\begin{array}{l}\text { Draws on the internal unit culture } \\
\text { (small mafia and give and take) } \\
\text { (h) }\end{array}$ & Downward \\
\hline R3 & $\begin{array}{l}\text { Being able to say what we } \\
\text { want to say to top } \\
\text { managers (1) }\end{array}$ & $\begin{array}{l}\text { Positions himself to } \\
\text { management as a } \\
\text { spokesperson for } \\
\text { technicians (11) }\end{array}$ & $\begin{array}{l}\text { Uses his frankness and his } \\
\text { voice to be heard by his } \\
\text { superiors (c) }\end{array}$ & $\begin{array}{l}\text { Hints at the communication } \\
\text { difficulties with his superiors (f) }\end{array}$ & Upward \\
\hline
\end{tabular}


Table AI. Continued

\begin{tabular}{|c|c|c|c|c|c|}
\hline & Performing the conversation & Setting the scene & $\begin{array}{l}\text { Symbolic and verbal } \\
\text { representations }\end{array}$ & Sociocultural systems & $\begin{array}{l}\text { Influence } \\
\text { direction }\end{array}$ \\
\hline $\mathrm{R} 4$ & $\begin{array}{l}\text { Uses his informal contacts } \\
\text { to assign employees to } \\
\text { teams }(4)\end{array}$ & $\begin{array}{l}\text { Knows 'who' can work } \\
\text { with 'whom' (7) }\end{array}$ & & $\begin{array}{l}\text { Hints at heavy bureaucracy of the } \\
\text { organization (f) } \\
\text { Activates knowledge about } \\
\text { internal networks not written } \\
\text { anywhere (f) }\end{array}$ & Downward \\
\hline R5 & $\begin{array}{l}\text { Uses the telephone to } \\
\text { reach people rapidly }(4)\end{array}$ & $\begin{array}{l}\text { Knows 'who' to get in } \\
\text { touch with in case of } \\
\text { problems }(6)\end{array}$ & $\begin{array}{l}\text { Communicates his } \\
\text { internal knowledge of } \\
\text { the organization (b) }\end{array}$ & $\begin{array}{l}\text { Uses his networks to solve } \\
\text { technical emergencies (f) }\end{array}$ & \\
\hline $\mathrm{R} 6$ & $\begin{array}{l}\text { Knows 'what' to say to } \\
\text { mobilize the technicians } \\
\text { (1) }\end{array}$ & $\begin{array}{l}\text { Knows 'who' to call in } \\
\text { emergency situation }(6)\end{array}$ & $\begin{array}{l}\text { Asks first about the } \\
\text { person, then he appeals } \\
\text { to team spirit (c) }\end{array}$ & $\begin{array}{c}\text { Turns away the hierarchy and } \\
\text { seniority rules and displays } \\
\text { appropriate attitudes }(\mathrm{g})\end{array}$ & $\begin{array}{r}\text { Upward and } \\
\text { downward }\end{array}$ \\
\hline R7 & $\begin{array}{l}\text { Recomposes the content } \\
\text { of his messages to } \\
\text { technicians about their } \\
\text { relationship with } \\
\text { Programme Production } \\
\text { Directorate (3) }\end{array}$ & $\begin{array}{l}\text { Integrates this message in } \\
\text { the routines of his unit } \\
\text { (9) }\end{array}$ & $\begin{array}{l}\text { Evokes the importance of } \\
\text { ties within his unit and } \\
\text { with management }(c)\end{array}$ & $\begin{array}{l}\text { Relies on the group culture (same } \\
\text { wavelength) (f) } \\
\text { Recalls his position of resistance } \\
\text { to management (f) }\end{array}$ & $\begin{array}{l}\text { Downward and } \\
\text { upward }\end{array}$ \\
\hline R8 & $\begin{array}{l}\text { Says what reassures } \\
\text { people }(2)\end{array}$ & $\begin{array}{l}\text { Meets the producer in } \\
\text { order to set new } \\
\text { collaboration relation } \\
\text { between the two } \\
\text { directorates }(9)\end{array}$ & $\begin{array}{l}\text { Refers directly to issue of } \\
\text { technical competence to } \\
\text { convince colleague (d) }\end{array}$ & $\begin{array}{l}\text { Refers to the historical competing } \\
\text { culture between the two } \\
\text { directorates }(\mathrm{h})\end{array}$ & Collateral \\
\hline \multicolumn{6}{|c|}{ William } \\
\hline W1 & $\begin{array}{l}\text { Uses specific language } \\
\text { (bottom line, cost, } \\
\text { profit, margin) (2) }\end{array}$ & & $\begin{array}{l}\text { Refers to importance of } \\
\text { translating everything } \\
\text { in quantitative } \\
\text { things/money (a) }\end{array}$ & $\begin{array}{l}\text { Understands cultural identity: } \\
\text { 'money men', 'accounting and } \\
\text { engineering people' (e) }\end{array}$ & Collateral \\
\hline W2 & $\begin{array}{l}\text { Develops message that } \\
\text { appeals to all in, e.g. } \\
\text { 'save this much' and } \\
\text { uses facts (1) }\end{array}$ & $\begin{array}{l}\text { Understands generically } \\
\text { the need for repeat } \\
\text { meetings to gradually } \\
\text { build buy-in (9) } \\
\text { Understands the need } \\
\text { to have analysis } \\
\text { previously prepared to } \\
\text { draw on, and to work } \\
\text { with different groups, } \\
\text { e.g. HR versus } \\
\text { executives }(9)\end{array}$ & $\begin{array}{l}\text { Puts attractive message } \\
\text { together by drawing on } \\
\text { representations that } \\
\text { appeal within Engco } \\
\text { culture, e.g. facts, } \\
\text { numbers, analysis to } \\
\text { create a 'package' (b) }\end{array}$ & $\begin{array}{l}\text { Understands autonomous nature } \\
\text { of divisions but also the need to } \\
\text { bring cross-divisional groups } \\
\text { together with commonalities } \\
\text { beyond the 'bottom line' }(\mathrm{h})\end{array}$ & $\begin{array}{l}\text { Collateral, } \\
\text { downward } \\
\text { and upward }\end{array}$ \\
\hline W3 & $\begin{array}{l}\text { Uses financial language } \\
\text { but also starts with } \\
\text { praise to the soften } \\
\text { message. Constructs a } \\
\text { story of why savings are } \\
\text { needed (3) }\end{array}$ & $\begin{array}{l}\text { Positions himself as a } \\
\text { seller instead of a teller } \\
\text { (11) }\end{array}$ & $\begin{array}{l}\text { Uses positive verbal } \\
\text { representation and } \\
\text { business motivations } \\
\text { instead of just 'we need } \\
\text { to reduce costs' (d) }\end{array}$ & $\begin{array}{l}\text { Recognizes the nature of his } \\
\text { relationship with the divisional } \\
\text { managers - no man date, } \\
\text { persuasion needed }(\mathrm{h})\end{array}$ & Collateral \\
\hline W4 & $\begin{array}{l}\text { Uses certain language 'the } \\
\text { logic' and appeals to } \\
\text { protocol, 'let me finish } \\
\text { before you make a } \\
\text { decision' }(4)\end{array}$ & $\begin{array}{l}\text { Knows which contacts to } \\
\text { use to access the board } \\
\text { (his boss in this case) (6) } \\
\text { Deliberately staging one } \\
\text { conversation to enable } \\
\text { another (9) } \\
\text { Prepares a presentation in } \\
\text { advance that will } \\
\text { appeal to the board ( } 8)\end{array}$ & $\begin{array}{l}\text { Once more recognizes the } \\
\text { need to position his } \\
\text { messages logically, and } \\
\text { builds a proposal (b) }\end{array}$ & $\begin{array}{l}\text { Recognizes constraints of existing } \\
\text { system (resistance remuneration } \\
\text { committee) (e) but also the } \\
\text { counter culture nature of his } \\
\text { proposal and the need to start } \\
\text { at the top (h) }\end{array}$ & $\begin{array}{l}\text { Upward } \\
\text { initially } \\
\text { to enable } \\
\text { collateral } \\
\text { and } \\
\text { downward }\end{array}$ \\
\hline W5 & $\begin{array}{l}\text { Links his work to the } \\
\text { board concerns e.g. the } \\
\text { balance sheet, risk, } \\
\text { liabilities (1) }\end{array}$ & $\begin{array}{l}\text { Positions himself as } \\
\text { business partner instead } \\
\text { a reporter in order to } \\
\text { make his view accepted } \\
\text { (11) }\end{array}$ & $\begin{array}{l}\text { Describes his role as } \\
\text { business focused (d) }\end{array}$ & $\begin{array}{l}\text { Understands need to change } \\
\text { relationship with board if he is } \\
\text { to exert more influence }(\mathrm{g})\end{array}$ & Upward \\
\hline W6 & $\begin{array}{l}\text { Is transparent. Argues for } \\
\text { building a 'process' a } \\
\text { 'logical framework' } \\
\text { rather than imposing a } \\
\text { decision (4) }\end{array}$ & $\begin{array}{l}\text { Designs meetings as } \\
\text { participative decision } \\
\text { making process, but } \\
\text { with arguments in place } \\
\text { to enable a rational } \\
\text { conclusion }(8)\end{array}$ & $\begin{array}{l}\text { Develops a logical } \\
\text { framework (b) }\end{array}$ & $\begin{array}{l}\text { Understands the suspicion of the } \\
\text { centre, the lack of a mandate } \\
\text { and the political turf issues (e) }\end{array}$ & Collateral \\
\hline
\end{tabular}


Table AI. Continued

\begin{tabular}{|c|c|c|c|c|c|}
\hline & Performing the conversation & Setting the scene & $\begin{array}{l}\text { Symbolic and verbal } \\
\text { representations }\end{array}$ & Sociocultural systems & $\begin{array}{l}\text { Influence } \\
\text { direction }\end{array}$ \\
\hline W7 & $\begin{array}{l}\text { Communicates to every } \\
\text { single person when } \\
\text { building the network (5) }\end{array}$ & $\begin{array}{l}\text { Develops networks } \\
\text { through face to face } \\
\text { meetings so that he can } \\
\text { subsequently use these } \\
\text { networks to perform } \\
\text { conversations on his } \\
\text { behalf }(10)\end{array}$ & & $\begin{array}{l}\text { Understands need to build } \\
\text { networks across business with } \\
\text { common agenda to facilitate } \\
\text { future change }(\mathrm{h})\end{array}$ & $\begin{array}{c}\text { Collateral and } \\
\text { downwards }\end{array}$ \\
\hline W8 & $\begin{array}{l}\text { Links his message to the } \\
\text { interests of the } \\
\text { recipient. For example, } \\
\text { addresses the agenda of } \\
\text { a boss through } \\
\text { someone else (1) }\end{array}$ & $\begin{array}{l}\text { Finds out why managers } \\
\text { are resistant, and uses } \\
\text { this to design a 'what is } \\
\text { in it for me' (9) }\end{array}$ & $\begin{array}{l}\text { Uses other people's } \\
\text { agendas and interests to } \\
\text { influence (d) }\end{array}$ & $\begin{array}{l}\text { Understands the political context } \\
\text { and the position of managers in } \\
\text { that context (f) }\end{array}$ & $\begin{array}{c}\text { Upward and } \\
\text { collateral }\end{array}$ \\
\hline $\begin{array}{l}\text { W9 } \\
\text { and } \\
\text { W10 }\end{array}$ & $\begin{array}{l}\text { Tailors conversations to } \\
\text { establish common } \\
\text { ground, but also } \\
\text { orchestrates } \\
\text { conversations to draw } \\
\text { on resources } \\
\text { appropriately such as } \\
\text { expert in audience, or } \\
\text { to set up a tactic like } \\
\text { 'good cop bad cop' (4) }\end{array}$ & $\begin{array}{l}\text { Engineers situations such } \\
\text { as who will be in the } \\
\text { audience, or his role in } \\
\text { comparison to that of } \\
\text { one of his team }(9)\end{array}$ & $\begin{array}{l}\text { Recognizes impact of } \\
\text { expert, subject related, } \\
\text { knowledge (b) }\end{array}$ & $\begin{array}{l}\text { Refers to social context (football } \\
\text { and Welsh ancestry) of the } \\
\text { managers he is talking to in } \\
\text { order to get their interest and } \\
\text { trust (g) }\end{array}$ & $\begin{array}{l}\text { Upward, } \\
\text { downward } \\
\text { and collateral }\end{array}$ \\
\hline \multicolumn{6}{|l|}{ Jane } \\
\hline J1 & $\begin{array}{l}\text { Persuades by being } \\
\text { reassuring about the } \\
\text { development of new } \\
\text { ideas for Engco (2) }\end{array}$ & $\begin{array}{l}\text { Positions herself as } \\
\text { representing the } \\
\text { interests of all divisions } \\
\text { rather than the Centre } \\
\text { (11) }\end{array}$ & $\begin{array}{l}\text { Knows innovation can't } \\
\text { be sold using traditional } \\
\text { representations to do } \\
\text { with bottom-line } \\
\text { performance (b) }\end{array}$ & $\begin{array}{l}\text { Recognizes that the divisions are } \\
\text { all powerful and hold all the } \\
\text { resources (e) }\end{array}$ & $\begin{array}{l}\text { Collateral and } \\
\text { downward }\end{array}$ \\
\hline $\mathrm{J} 2$ & $\begin{array}{l}\text { Engages people through } \\
\text { face to face meetings }(4)\end{array}$ & $\begin{array}{l}\text { Use of different forums to } \\
\text { draw together } \\
\text { individuals she works } \\
\text { with and keep them } \\
\text { informed (8) }\end{array}$ & & $\begin{array}{l}\text { Sees need to work through } \\
\text { networks in context of } \\
\text { autonomous, silo divisions (h) }\end{array}$ & Downward \\
\hline J3 & $\begin{array}{l}\text { Talks about different } \\
\text { issues in order to } \\
\text { activate the links with } \\
\text { coordinators and } \\
\text { facilitators; uses } \\
\text { different media to } \\
\text { perform conversation } \\
(4)\end{array}$ & $\begin{array}{l}\text { Knowing that face-to-face } \\
\text { best way to engage but } \\
\text { that other media can } \\
\text { help, e.g. audio } \\
\text { conferences, newsletters } \\
\text { (8) }\end{array}$ & $\begin{array}{l}\text { Tries to find language that } \\
\text { will connect, e.g. prizes } \\
\text { (a) }\end{array}$ & $\begin{array}{l}\text { Recognizes how difficult it is to } \\
\text { communicate across divisions } \\
\text { (g) }\end{array}$ & $\begin{array}{l}\text { Collateral and } \\
\text { downward }\end{array}$ \\
\hline $\mathrm{J} 4$ & $\begin{array}{l}\text { Positions projects with } \\
\text { different benefits for } \\
\text { different potential } \\
\text { sponsors. Focuses on } \\
\text { what can be achieved } \\
\text { short-term to match } \\
\text { short-term horizon of } \\
\text { managers (1) }\end{array}$ & $\begin{array}{l}\text { Identifies who to sell a } \\
\text { project to }(6) \\
\text { Identifies the appropriate } \\
\text { timing for the sales } \\
\text { pitch }(8) \text { Identifies } \\
\text { parcels of benefits to } \\
\text { match managers' time } \\
\text { horizons (9) }\end{array}$ & $\begin{array}{l}\text { Uses context specific } \\
\text { language, such as } \\
\text { benefits and parcels of } \\
\text { benefits to match } \\
\text { managerial focus on } \\
\text { results (a) }\end{array}$ & $\begin{array}{l}\text { Knows that power base lies with } \\
\text { general managers, and that } \\
\text { focus is on short term } \\
\text { performance (2) } \\
\text { Also knows different divisional } \\
\text { interests (e) }\end{array}$ & Upward \\
\hline J5 & $\begin{array}{l}\text { Generates a flow of } \\
\text { conversations that } \\
\text { created alternative } \\
\text { connections between } \\
\text { facilitators }(5)\end{array}$ & $\begin{array}{l}\text { Organizes a roadshow } \\
\text { and timetable to build } \\
\text { alternative } \\
\text { communication } \\
\text { channels across silo } \\
\text { divisions (8) }\end{array}$ & & $\begin{array}{l}\text { Recognizes the divisional and silo } \\
\text { based nature of the } \\
\text { organization }(\mathrm{h})\end{array}$ & Downward \\
\hline J6 & $\begin{array}{l}\text { Use of persuasive } \\
\text { language: tomorrow } \\
\text { versus today's results. (3) } \\
\text { Everything couched in } \\
\text { terms of 'benefits' to } \\
\text { divisions to win their } \\
\text { support and their } \\
\text { funding (2) }\end{array}$ & & $\begin{array}{l}\text { Sees conflict in results } \\
\text { based, short-term } \\
\text { performance language } \\
\text { of organization and } \\
\text { need to invest in } \\
\text { innovation }(\mathrm{d})\end{array}$ & $\begin{array}{l}\text { Knows that hierarchical nature of } \\
\text { organization and need to } \\
\text { constantly release resources } \\
\text { from divisions does not fit with } \\
\text { innovation (e) }\end{array}$ & Upward \\
\hline
\end{tabular}


Table AI. Continued

\begin{tabular}{|c|c|c|c|c|c|}
\hline & Performing the conversation & Setting the scene & $\begin{array}{l}\text { Symbolic and verbal } \\
\text { representations }\end{array}$ & Sociocultural systems & $\begin{array}{l}\text { Influence } \\
\text { direction }\end{array}$ \\
\hline $\mathrm{J} 7$ & & $\begin{array}{l}\text { Uses the legitimacy of the } \\
\text { steering committee }(6)\end{array}$ & & $\begin{array}{l}\text { Recognizes the power of the } \\
\text { divisions (e) }\end{array}$ & Downward \\
\hline J8 & $\begin{array}{l}\text { Uses influential } \\
\text { individuals, here the } \\
\text { CEO, to build support } \\
\text { (4) }\end{array}$ & $\begin{array}{l}\text { Organizes an innovation } \\
\text { summit that brings } \\
\text { together supporters: } \\
\text { draws on power of } \\
\text { others }(7)\end{array}$ & $\begin{array}{l}\text { Can't easily connect to } \\
\text { contextually relevant } \\
\text { symbolic and verbal } \\
\text { representations, so uses } \\
\text { powerful individuals } \\
\text { instead (c) }\end{array}$ & $\begin{array}{l}\text { Recognizes culture of } \\
\text { organization will respond to } \\
\text { very senior sponsorship (f) }\end{array}$ & Collateral \\
\hline J9 & & $\begin{array}{l}\text { Uses her personal network } \\
(7)\end{array}$ & & $\begin{array}{l}\text { Understands need for networks to } \\
\text { enable work from Centre: no } \\
\text { mandate }(\mathrm{h})\end{array}$ & $\begin{array}{c}\text { Collateral and } \\
\text { interface }\end{array}$ \\
\hline
\end{tabular}

\section{AGKNOWLEDGMENTS}

We would like to thank Ann Langley and David Sims for comments on early drafts of this paper. We would also like to thank the editor and three anonymous reviewers for their insightful reviews and commentary. They have helped us to significantly strengthen this paper. The authors also gratefully acknowledge financial support in the preparation of this manuscript from the UK ESRC/EPSRC/Advanced Institute of Management (AIM) Research: RES-331-25-3014. The data used in this paper by the first author was collected through a research project financially supported by the Social Sciences and Humanities Research Council (SSHRC) of Canada. The data contributed to this paper by the second author was collected as part of a larger academic/practitioner research partnership called the Change Management Consortium.

\section{NOTES}

[1] Our thanks to reviewer 2 for helping us to strengthen our methodological justification.

[2] The data collection was not designed to highlight multiway activity, but the multiway nature still emerged from the data.

\section{REFERENGES}

Alexiev, A. S., Jansen, J. J. P., Van den Bosch, F. A. J. and Volberda, H. W. 'Top management team advice seeking and exploratory innovation: the moderating role of TMT heterogeneity'. Fournal of Management Studies, doi: 10.1111/j.1467-6486.2010.00919 (forthcoming).

Balogun, J. (2003). 'From blaming the middle to harnessing its potential: creating change intermediaries'. British Fournal of Management, 14, 69-83.

Balogun, J. and Johnson, G. (2004). 'Organizational restructuring and middle manager sensemaking'. Academy of Management Fournal, 47, 523-49.

Balogun, J. and Johnson, G. (2005). 'From intended strategy to unintended outcomes: the impact of change recipient sensemaking'. Organization Studies, 26, 1573-602.

Balogun, J., Huff, A. and Johnson, P. (2003). 'Three responses to the methodological challenges of studying strategizing'. Fournal of Management Studies, 40, 197-224.

Balogun, J., Hope Hailey, V., Gleadle, P. and Willmott, H. (2005). 'Managing change across boundaries: boundary shaking practices'. British Fournal of Management, 16, 261-78.

Balogun, J., Pye, A. and Hodgkinson, G. (2008). 'Cognitively skilled organizational decision making: making sense of deciding'. In Hodgkinson, G. and Starbuck, W. H. (Eds), The Oxford Handbook of Organizational Decision Making. Oxford: Oxford University Press.

Bertaux, D. and Delcroix, C. (2000). 'Case histories of families and social processes'. The Turn to Biographical Methods in Social Sciences: Comparative Issues and Examples. London: Routledge.

Buchanan, D. A. (2008). 'You stab my back, I'll stab yours: management experience and perceptions of organization political behaviour'. British fournal of Management, 19, 49-64. 
Corley, K. G. and Gioia, D. A. (2004). 'Identity ambiguity and change in the wake of a corporate spin-off'. Administrative Science Quarterly, 49, 173-208.

Currie, G. (1999). 'The influence of middle managers in the business planning process: a case study in a UK NHS'. British fournal of Management, 10, 141-56.

Currie, G. and Proctor, S. (2005). 'The antecedents of middle managers' strategic contribution: the case of a professional bureaucracy'. Fournal of Management Studies, 42, 1325-56.

Dutton, J. E. and Ashford, S. J. (1993). 'Selling issues to top management'. Academy of Management Revierw, 18, 397-428.

Dutton, J. E., Ashford, S. J., Wierba, E. E., O’Neil, R. and Hayes, E. (1997). 'Reading the wind: how middle managers assess the context for issue selling to top managers'. Strategic Management Fournal, 15, $407-25$.

Dutton, J. E., Ashford, S. J., O’Neil, R. and Lawrence, K. A. (2001). 'Moves that matter: issue selling and organizational change'. Academy of Management Fournal, 44, 716-36.

Fairhurst, G. (2007). Discursive Leadership: In Conversation with Leadership Psychology. Thousand Oaks, CA: Sage.

Floyd, S. W. and Lane, P. J. (2000). 'Strategizing throughout the organization: management role conflict in strategic renewal'. Academy of Management Review, 25, 154-77.

Floyd, S. W. and Wooldridge, B. (1994). 'Dinosaurs or dynamos? Recognizing middle management's strategic role'. Academy of Management Executive, $\mathbf{8}, 47-57$.

Floyd, S. W. and Wooldridge, B. (1997). 'Middle management's strategic influence and organizational performance'. Fournal of Management Studies, 34, 465-86.

Gioia, D. A. and Chittipeddi, K. (1991). 'Sensemaking and sensegiving in strategic change initiation'. Strategic Management Fournal, 12, 433-48.

Gioia, D. A. and Longenecker, C. O. (1994). 'Delving into the dark side: the politics of executive appraisal'. Organizational Dynamics, 22, 47-58.

Hoon, C. (2007). 'Committees as strategic practice: the role of strategic conversation in a public administration'. Human Relations, 60, 921-52.

Huy, Q. N. (2002). 'Emotional balancing of organizational continuity and radical change: the contribution of middle managers'. Administrative Science Quarterly, 47, 31-69.

Jarzabkowski, P., Balogun, J. and Seidl, D. (2007). 'Strategizing: the challenge of a practice perspective'. Human Relations, 60, 5-27.

Johnson, G., Melin, L. and Whittington, R. (2003). 'Micro-strategy and strategizing: toward an activitybased view'. Fournal of Management Studies, 40, 3-22.

Laine, P. M. and Vaara, E. (2007). 'Struggling over subjectivity: a discourse analysis of strategic development in an engineering group'. Human Relations, 59, 611-36.

Langley, A. (1999). 'Strategies for theorizing from process data'. Academy of Management Review, 24, 691-710.

Lawrence, T., Mauws, M. K., Byck, B. and Kleysen, R. F. (2005). 'The politics of organizational learning: integrating power into the 4I framework'. Academy of Management Review, 30, 180-91.

Ling, Y., Floyd, S. W. and Baldridge, D. C. (2005). 'Reading the wind in multinational corporations. The impact of culture in issue selling behavior'. Fournal of International Business Studies, 36, 637-54.

Maitlis, S. (2005). 'The social processes of organizational sensemaking'. Academy of Management Fournal, $\mathbf{4 8 ,}$ 21-49.

Maitlis, S. and Lawrence, T. (2007). 'Triggers and enablers in organizations'. Academy of Management Fournal, 50, 57-84.

Maitlis, S. and Sonenshein, S. (2010). 'Sensemaking in crisis and change: inspiration and insights from Weick (1988)'. Fournal of Management Studies, 47, 551-80.

Mangham, I. L. and Pye, A. (1991). The Doing of Managing. Oxford: Blackwell.

Mantere, S. (2008). 'Role expectations and middle manager strategic agency'. Fournal of Management Studies, 45, 294-316.

Orlikowski, W. J. (2002). 'Knowing in practice: enacting a collective capability in distributed organizing'. Organization Science, 13, 249-73.

Piderit, S. K. and Ashford, S. J. (2003). 'Breaking silence: tactical choices women managers make in speaking up about gender-equity issues'. Fournal of Management Studies, 40, 1477-502.

Pye, A. (1995). 'Strategy through dialogue and doing: a game of Mornington Crescent?'. Management Learning, 26, 445-62.

Pye, A. (2002). 'The changing power of "explanations": directors, academics and their sensemaking from 1989 to 2000'. Fournal of Management Studies, 39, 907-25.

Pye, A. and Pettigrew, A. (2005). 'Studying board context, process and dynamics: some challenges for the future'. British Fournal of Management, 16, 27-38. 
Raman, S. R. (2009). 'Middle managers' involvement in strategic planning: an examination of roles and influencing factors'. Fournal of General Management, 34, 57-74.

Rouleau, L. (2005). 'Micro-practices of strategic sensemaking and sensegiving: how middle managers interpret and sell change every day'. Fournal of Management Studies, 42, 1413-43.

Rouleau, L. (2010). 'Studying strategizing through narratives of practice'. In Golsorkhi, D., Rouleau, L., Seidl, D., and Vaara, E. (Eds), Cambridge Handbook of Strategy as Practice. Cambridge: Cambridge University Press, 258-70.

Samra-Fredericks, D. (2005). 'Strategy practice, discourse and the everyday interactional constitution of power effects'. Organization, 12, 803-41.

Sonenshein, S. (2006). 'Crafting social issues at work'. Academy of Management fournal, 49, 1158-72.

Taylor, J. R. and Robichaud, D. (2004). 'Finding the organization in the communication: discourse as action and sensemaking'. Organization, 11, 395-414.

Watson, T. J. and Bargiela-Chiappini, F. (1998). 'Managerial sensemaking and occupational identities in Britain and Italy: the role of management magazines in the process of discursive construction'. Fournal of Management Studies, 35, 285-301.

Weick, K. E. (1995). Sensemaking in Organizations. London: Sage.

Westley, F. (1990). 'Middle managers and strategy: micro dynamics of inclusion'. Strategic Management fournal, 11, 337-51.

Wooldridge, B., Schmid, T. and Floyd, S. W. (2008). 'The middle management perspective on strategy process: contributions, synthesis, and future research'. Fournal of Management, 34, 1190-221.

Yang, J., Zhang, Z.-X. and Tsui, A. S. 'Middle manager leadership and frontline employee performance: bypass, cascading, and moderating effects'. Fournal of Management Studies, 47, 654-78. 